\title{
The Involvement of Nitric Oxide in the Inhibition of the Phosphoroclastic System in Clostridium sporogenes by Sodium Nitrite
}

\author{
By LEONARD F. J. WOODS, * JOHN M. WOOD AND \\ PAUL A. GIBBS \\ Microbiology Section, Leatherhead Food Research Association, Randalls Road, \\ Leatherhead, Surrey KT22 7RY, U.K.
}

(Received 8 January 1981; revised 12 February 1981)

\begin{abstract}
The phosphoroclastic system was demonstrated in cell-free extracts of Clostridium sporogenes by the production of carbon dioxide, acetyl phosphate, ATP and reduced NAD in the presence of pyruvate. The kinetics of acetyl phosphate production and NAD reduction were investigated. The addition of sodium nitrite to a suspension of $C$. sporogenes in glucose medium resulted in a rapid decrease in intracellular ATP concentration which was accompanied by an accumulation of pyruvate in the medium. This accumulation of pyruvate was caused by inhibition of the phosphoroclastic system by nitrite. Nitrite inhibits this system by reaction of nitric oxide, formed from nitrite, with the non-haem iron of pyruvate : ferredoxin oxidoreductase.
\end{abstract}

\section{INTRODUCTION}

The effect of sodium nitrite on the germination and outgrowth of bacterial spores and growth of food spoilage organisms in complex meat systems has been extensively investigated in relation to the use of nitrite in meat curing (Duncan \& Foster, 1968). However, less attention has been given to the effect of nitrite on bacterial growth in simple media systems, particularly its effect on the physiology of the microbial cell.

Of particular interest in this context is the mechanism by which nitrite inhibits the growth of the food pathogen Clostridium botulinum. Recent work with aerobic bacteria has shown that nitrite inhibits oxidative phosphorylation causing a decrease in energy-dependent functions such as active transport (Rowe et al., 1979; Yarbrough et al., 1980). This suggested to us that the analogous system, i.e. substrate level phosphorylation, might be the site of action of nitrite in clostridia.

Some enzymes of glucose fermentation in $C$. perfringens, namely glyceraldehyde3-phosphate dehydrogenase and aldolase, have been shown to be inhibited by nitrite (O'Leary \& Solberg, 1976). However, the concentration of nitrite required (15 mM) was greater than that known to inhibit the growth of $C$. sporogenes $(1.4 \mathrm{~mm}$ at $\mathrm{pH} 6.0$ ) (Duncan \& Foster, 1968). An important source of ATP in clostridia is the phosphoroclastic system in which pyruvate is oxidized to acetate, with carbon dioxide and hydrogen being formed as by-products. We report here the effects of nitrite on this system in $C$. sporogenes and propose a mechanism to explain these effects.

\section{METHODS}

Preparation of cell-free extracts. Clostridium sporogenes (mixed culture, NCIB 8053 and 10696) was grown in Oxoid nutrient broth no. 2 containing $1 \%(\mathrm{w} / \mathrm{v})$ glucose autoclaved at $121{ }^{\circ} \mathrm{C}$ for $15 \mathrm{~min}$. Prior to inoculation the medium was placed in a boiling-water bath for $1 \mathrm{~h}$ and then cooled rapidly. Anaerobic conditions were achieved by 
the addition of $5 \mathrm{ml}$ sterile $10 \%(\mathrm{w} / \mathrm{v})$ sodium thioglycollate per litre medium. The medium was inoculated with $10 \mathrm{ml}$ suspension of actively growing clostridia [grown for $21 \mathrm{~h}$ at $37^{\circ} \mathrm{C}$ in $1 \%(\mathrm{w} / \mathrm{v})$ glucose nutrient broth] per litre and incubated at $37^{\circ} \mathrm{C}$ for $21 \mathrm{~h}$. The cells were then harvested by centrifugation at $10000 \mathrm{~g}_{\mathrm{av}}$ for $5 \mathrm{~min}$ and washed once in $0.1 \mathrm{M}$-potassium phosphate buffer, $\mathrm{pH} 6.5$, to yield about $4 \mathrm{~g}$ cells (wet wt) per litre medium. The washed cells were suspended in $15 \mathrm{ml}$ buffer and placed in an X-press (Biotec, Croydon, U.K.) previously cooled to $-30^{\circ} \mathrm{C}$. The cells were disrupted by making three passages through the $\mathrm{X}$-press and, once the frozen pellet had thawed, cellular debris was removed by centrifugation for $15 \mathrm{~min}$ at $10000 \mathrm{~g}_{\mathrm{av}}$ at $4{ }^{\circ} \mathrm{C}$. The clear brown supernatant was decanted, saturated with oxygen-free nitrogen and stored in a stoppered tube in ice. All manipulations were performed, as far as possible, under anaerobic conditions on ice; cell suspensions and buffers were saturated with oxygen-free nitrogen.

Analytical methods.

Gas production: Gas production was measured by standard manometric techniques using Warburg manometers (Umbreit et al., 1957) incubated at $37^{\circ} \mathrm{C}$ in a Series III Warburg apparatus (Townson \& Mercer, Croydon, U.K.).

Acetyl phosphate: Acetyl phosphate production from pyruvate was measured by a method adapted from that of Lipmann \& Tuttle (1945). Cell-free extract, pyruvate and buffer were incubated together at room temperature in $1 \mathrm{ml}$ total volume for $2 \mathrm{~min}$. The production of acetyl phosphate was terminated by the addition of $1 \mathrm{ml}$ of ice-cold neutral hydroxylamine hydrochloride (made by mixing equal volumes of $4 \mathrm{M}$-hydroxylamine hydrochloride and $3.5 \mathrm{M}-\mathrm{NaOH}$ ). This mixture was incubated at room temperature for $10 \mathrm{~min}$ to allow the formation of acetylhydroxamic acid. The solution was then deproteinized and a purple complex was formed with $\mathrm{Fe}$ (III) by adding $1 \mathrm{ml}$ each of $2.5 \mathrm{M}-\mathrm{HCl}, 0.74 \mathrm{M}$-trichloroacetic acid (TCA) and $0.19 \mathrm{M}$-ferric chloride in $0.1 \mathrm{M}-\mathrm{HCl}$. Absorbance was measured at $500 \mathrm{~nm}(1 \mathrm{~cm}$ path length; Pye Unicam SP6-350 visible spectrophotometer). The

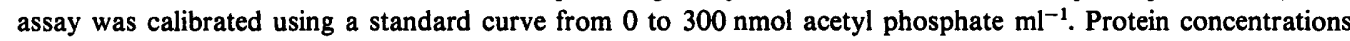
were determined by the Lowry method using bovine serum albumin as the standard.

ATP: ATP was measured by means of an LKB Luminometer 1250 using LKB ATP monitoring reagent consisting of standardized purified luciferin-luciferase (Myhrman et al., 1978). To measure ATP production by the cell-free system, $0.1 \mathrm{ml}$ ATP monitoring reagent was added to $0.6 \mathrm{ml} 0.1 \mathrm{M}$-phosphate buffer, $\mathrm{pH} 6.5$ and $0.2 \mathrm{ml}$ cell-free extract. When a steady baseline was achieved (usually after $1-2 \mathrm{~min}$ ) pyruvate was added and the increase in luminescence due to ATP production recorded.

To measure the ATP content of whole cells, the suspension was first diluted $10^{-3}$-fold with sterile water and then a sample was mixed with an equal volume of NRB reagent (Nucleotide Releasing Agent for Bacterial Cells; Hermitage Instrumentation, Wimborne Minster, Dorset), to release ATP from the cells. A sample of this solution $(0.1 \mathrm{ml})$ was added to $0.2 \mathrm{ml}$ ATP monitoring reagent and $0.7 \mathrm{ml} 0.02 \mathrm{M}$-borate buffer, $\mathrm{pH} 7.4$ and the luminescence was recorded. The system was calibrated using standards containing from $1.6 \times 10^{-10}$ to

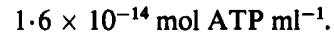

For the results presented in Fig. 1, the cells from 1 litre of medium were resuspended in $100 \mathrm{ml}$ nutrient broth containing $1 \%(\mathrm{w} / \mathrm{v})$ glucose $(\mathrm{pH} 6.0)$ and incubated at $37^{\circ} \mathrm{C}$. When ATP was being actively produced and pyruvic acid concentrations had stabilized, solid sodium nitrite was addedto give a final concentration of $4.4 \mathrm{mM}$.

Pyruvic acid and glucose: Pyruvic acid was estimated by means of a pyruvic acid determination kit (Sigma) in which the decrease in NADH concentration catalysed by lactate dehydrogenase was measured at $340 \mathrm{~nm}$. For the results presented in Fig. 1, pyruvic acid was measured by first adding $1 \mathrm{ml}$ of cell suspension to $1 \mathrm{ml}$ of ice-cold $12 \%(\mathrm{w} / \mathrm{v})$ TCA (to prevent further accumulation of pyruvate) and then adding $0.5 \mathrm{ml}$ of this solution to $2 \mathrm{ml}$ $0.1 \mathrm{M}$-phosphate buffer, $\mathrm{pH} 6.5$ and $0.5 \mathrm{ml} 0.66 \mathrm{mM}-\mathrm{NADH}$ solution $(0.11 \mathrm{~mm}$ final concentration). The amount of pyruvic acid was determined by recording the decrêase in $A_{340}$ when 50 units of lactic dehydrogenase was added. The system was calibrated using a standard solution containing $0.4 \mathrm{mg}$ pyruvic acid $\mathrm{ml}^{-1}$ $\left(0.46 \mu \mathrm{mol} \mathrm{ml}{ }^{-1}\right)$. The suspension contained $1.3 \pm 0.3 \times 10^{9}$ cells $\mathrm{ml}^{-1}(n=18)$ as determined using a haemocytometer (Weber Scientific Instruments, Lancing, U.K.). There was no increase in the number of cells during the course of the experiment. The glucose concentration of the TCA-treated samples was measured by means of glucose single assay vials (Sigma).

NAD reduction: The pyruvate-dependent reduction of NAD catalysed by the cell-free extract was measured by the increase in absorbance at $340 \mathrm{~nm}$. A molar extinction coefficient of $6.22 \times 10^{3} 1 \mathrm{~mol}^{-1} \mathrm{~cm}^{-1}$ was used. The pyruvate concentration, unless otherwise stated, was $0.6 \mathrm{mM}$ and $20-30 \mathrm{mg}$ protein from the cell-free extract in a final volume of $2.5 \mathrm{ml}$ were used. No additional cofactors were required; incubations were carried out at room temperature $\left(20^{\circ} \mathrm{C}\right)$.

Nitric oxide: Nitric oxide was measured by a chemiluminescence method (Glover, 1975) using a British Oxygen Luminox 101A chemiluminescence analyser. Samples were injected into boiling $0.5 \mathrm{M}-\mathrm{NaOH}$ to prevent non-enzymic production of nitric oxide.

$D E A E$-cellulose chromatography. The separation of the acidic protein, ferredoxin, from the remainder of the protein in the cell-free extract was achieved by DEAE-cellulose chromatography. This technique is well established 
as the first step in the purification of clostridial ferredoxins (Mortenson et al., 1962). The $10000 \mathbf{g}_{\mathrm{av}}$ supernatant (about $15 \mathrm{ml}$ ) from the disruption of the cells from 1 litre of medium was passed through a Whatman DE52 column $(0.5 \times 1 \mathrm{~cm}$; volume approximately $0.5 \mathrm{ml})$ previously equilibrated with $0.1 \mathrm{M}$-phosphate buffer, $\mathrm{pH} 6.5$. Only a small column was required since the ferredoxin was bound strongly by the column to form a dark brown band 2-3 mm deep; the remainder of the protein passed through the column and was collected. After washing with $0.1 \mathrm{M}$-phosphate buffer the ferredoxin was eluted from the column using $5 \mathrm{ml} 0.75 \mathrm{M}$-phosphate buffer, $\mathrm{pH} 6 \cdot 5$. A typical recovery from the column, as measured by the total protein the two fractions, was $70 \%$.

The reconstituted system, capable of pyruvate-dependent NAD reduction, consisted of $1 \mathrm{ml} 0.1 \mathrm{M}$-phosphate buffer, $\mathrm{pH} 6.5,1 \mathrm{ml}$ protein fraction (in the same buffer) and $0.2 \mathrm{ml}$ ferredoxin fraction in $0.75 \mathrm{M}$-phosphate buffer, $\mathrm{pH} 6.5$. The reaction was started by adding $0.2 \mathrm{ml} 7.3 \mathrm{mM}$-sodium pyruvate in $0.1 \mathrm{M}$-phosphate buffer (final concentration of $0.6 \mathrm{~mm}$-pyruvate).

Chemicals. Sodium pyruvate, hydroxylamine hydrochloride, açetyl phosphate, bovine serum albumin, Folin \& Ciocalteau's reagent, NAD, NADP and ferredoxin purified from Clostridium pasteurianum were obtained from Sigma. Oxygen-free nitrogen and nitric oxide were obtained from BOC, Special Gases, Deer Park Road, London.

\section{RESULTS}

\section{Effect of nitrite on whole cells}

When sodium nitrite ( $4.4 \mathrm{~mm}$ final concentration) was added to cultures of $C$. sporogenes growing in nutrient broth containing glucose there was a rapid decrease in the intracellular concentration of ATP and a marked increase in the pyruvate concentration of the medium (Fig. 1). Gas chromatographic analysis of the medium showed that during a $2 \mathrm{~h}$ incubation nitrite also caused a decrease in the amount of acetate produced from 0.5 to $0.2 \mathrm{nmol}$ per $10^{6}$ cells. The accumulation of pyruvate shows that nitrite was inhibiting the phosphoroclastic system.

Carbon dioxide and hydrogen were produced by $C$. sporogenes at similar rates over a 60 min incubation. The presence of hydrogen as a product of glucose fermentation was confirmed by gas chromatography. Addition of $1.5 \mathrm{mM}$-sodium nitrite to the culture inhibited the rate of carbon dioxide production by $56 \%$ and hydrogen production by $48 \%$, as determined by Warburg manometry.

In addition, nitrite inhibited the uptake of glucose by the clostridia. Organisms growing in nutrient broth containing $1 \%(\mathrm{w} / \mathrm{v})$ glucose were harvested and resuspended in medium containing $0.1 \%(\mathrm{w} / \mathrm{v})$ glucose and either $4.4 \mathrm{~mm}$-sodium nitrite or $20 \mathrm{mM}$-sodium fluoride. Analysis of the amounts of glucose remaining in the medium showed that uptake was complete after $30 \mathrm{~min}$ in control cultures while the presence of nitrite caused a $50 \%$ inhibition of this rate. Complete inhibition of glucose uptake was obtained with fluoride, presumably as a consequence of the inhibition of enolase (Bücher, 1955).

\section{Studies with cell-free extracts}

Carbon dioxide production from pyruvate. The cell-free extract of $C$. sporogenes incubated at $37^{\circ} \mathrm{C}$ with $23 \mathrm{~mm}$-pyruvate produced gas at a constant rate for over $30 \mathrm{~min}$, after an initial lag phase of $5 \mathrm{~min}$, as measured by Warburg manometry. This gas was completely absorbed by potassium hydroxide and was therefore tentatively identified as carbon dioxide. No hydrogen was produced indicating the absence of hydrogenase activity.

Kinetics of acetyl phosphate production. The kinetics of acetyl phosphate production from pyruvate by cell-free extracts from $C$. sporogenes was investigated without the addition of cofactors such as thiamin pyrophosphate, coenzyme A or NAD (Wolfe \& O'Kane, 1953). The Michaelis constant for pyruvate was determined as $2.4 \mathrm{mM}$ and the maximum rate was $37 \mathrm{nmol}$ acetyl phosphate $\mathrm{min}^{-1}$ (mg protein) $)^{-1}$. The rate of acetyl phosphate production was not inhibited by sodium nitrite up to $24 \mathrm{~mm}$.

ATP production. The rate of ATP production in a cell-free system was $0.14 \times 10^{-12} \mathrm{~mol}$ ATP $\min ^{-1}$ (mg protein) ${ }^{-1}$ at a pyruvate concentration of $0.7 \mathrm{mM}$. Sodium nitrite $(16 \mathrm{mM})$ caused $30 \%$ inhibition of ATP production. 


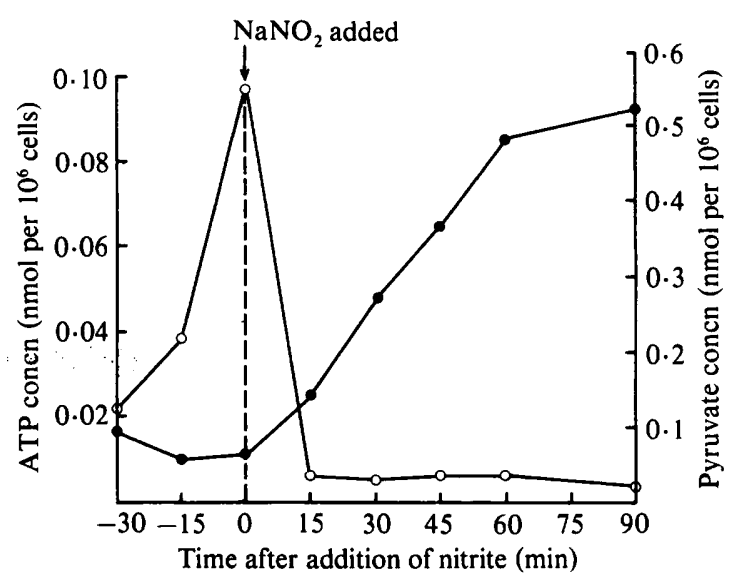

Fig. 1. Effect of $4.4 \mathrm{mM}$-nitrite added (at time 0 ) to a culture of $C$. sporogenes incubated at $37{ }^{\circ} \mathrm{C}: \mathrm{O}$, intracellular ATP concentration;, , pyruvate concentration in the medium.

Kinetics of NAD reduction. The addition of pyruvate to the cell-free system resulted in the reduction of endogenous NAD. There was an initial delay in NAD reduction presumably due to a requirement to accumulate reduced intermediates before reduction could occur. The reaction ceased after about $4 \mathrm{~min}$. It could not be stimulated by the addition of further pyruvate, whereas addition of NAD resulted in a rapid increase in the amount of reduced NAD. Subsequent addition of NADP caused a rapid decrease in absorbance at $340 \mathrm{~nm}$.

The enzyme system responsible for NAD reduction was very labile: $50 \%$ of the activity disappeared after $4.5 \mathrm{~h}$ at $0^{\circ} \mathrm{C}$ even under anaerobic conditions and overnight storage at $-20^{\circ} \mathrm{C}$ resulted in complete loss of activity. The ability to produce ATP was also lost after storage at $-20^{\circ} \mathrm{C}$. This is in contrast to the acetyl phosphate-producing activity which was stable to storage under these conditions. NAD reduction was also sensitive to oxygen: bubbling air through the system caused both a decrease in the rate and an increase in the delay before NAD reduction.

The maximum rate of NAD reduction by the cell-free extract $14 \mathrm{nmol} \mathrm{min}{ }^{-1}$ (mg protein $)^{-1}$ ] was obtained at a pyruvate concentration of $0.4 \mathrm{mM}$. A plot of rate against pyruvate concentration was sigmoidal indicating that the rate-determining enzyme in NAD reduction is an allosteric enzyme.

The pyruvate-dependent reduction of NAD was inhibited by sodium nitrite: $8 \mathrm{~mm}$-nitrite caused a $50 \%$ inhibition of rate while the lag period increased with increasing nitrite concentration.

\section{Site of action of nitrite and nitric oxide}

Ferredoxin was separated from other proteins in the cell-free extract by DEAE-cellulose chromatography. Subsequently, the pyruvate-dependent NAD-reducing activity could be reconstituted. Increasing the amount of ferredoxin in the reconstituted system caused an increase in the rate of NAD reduction and a decrease in the length of the lag period. The system could also be reconstituted using a commercially available ferredoxin purified from $C$. pasteurianum.

Sodium nitrite inhibited the reconstituted system to the same extent as the cell-free system. Nitrite did not react directly with ferredoxin since preincubation of this fraction with 6 mM-nitrite, which would produce $40 \%$ inhibition in the whole system, caused less than $20 \%$ inhibition. This low inhibition was due to the nitrite carried over during subsequent reconstitution resulting in a final nitrite concentration of $0.6 \mathrm{mM}$. 
Table 1. Effect of incubating cells with nitrite on the reconstituted phosphoroclastic system

Cells were incubated with $4.4 \mathrm{~mm}$-nitrite at $37^{\circ} \mathrm{C}$ for $1 \mathrm{~h}$ (or left untreated) before disruption and separation of the ferredoxin and protein fractions. The phosphoroclastic system was reconstituted from the fractions indicated.

\begin{tabular}{|c|c|c|c|c|}
\hline $\begin{array}{l}\text { Protein } \\
\text { fraction }\end{array}$ & $\begin{array}{l}\text { Ferredoxin } \\
\text { fraction }\end{array}$ & $\begin{array}{l}\text { Maximum rate of NAD reduction } \\
{\left[\text { nmol } \mathrm{min}^{-1}(\mathrm{mg} \text { protein })^{-1}\right]}\end{array}$ & $\begin{array}{l}\text { Total } \\
\text { protein } \\
\text { (mg) }\end{array}$ & $\begin{array}{l}\text { Ferredoxin } \\
\text { protein } \\
(\mathrm{mg})\end{array}$ \\
\hline Control & Control & 0.86 & $71 \cdot 5$ & 1.0 \\
\hline Control & Nitrite-treated & $0 \cdot 16$ & $71 \cdot 0$ & 0.5 \\
\hline Nitrite-treated & Control & 0.00 & $58 \cdot 0$ & $1 \cdot 0$ \\
\hline Nitrite-treated & Nitrite-treated & 0.00 & $57 \cdot 5$ & 0.5 \\
\hline
\end{tabular}

The effect of incubating $C$. sporogenes cells in medium containing 4.4 mM-sodium nitrite on the two parts of the reconstituted system was investigated. Cells grown in the normal way were resuspended in fresh medium adjusted to $\mathrm{pH} 6.0$ containing nitrite and incubated at $37^{\circ} \mathrm{C}$ for $1 \mathrm{~h}$. They were then disrupted and the ferredoxin and protein fractions were separated by DEAE-cellulose chromatography. The nitrite-treated $10000 \boldsymbol{g}_{\text {av }}$ supernatant was much paler than the control and when the systems were reconstituted no NAD-reducing activity could be found with the nitrite-treated protein fraction even with control ferredoxin (Table 1). The nitrite-treated ferredoxin fraction contained less protein than did the control but retained some activity.

Nitric oxide caused an inhibition of NAD reduction in the reconstituted system. When nitric oxide was passed through the ferredoxin fraction prior to reconstitution there was a $60 \%$ decrease in the rate of NAD reduction. Passing nitric oxide through the protein fraction caused a $40 \%$ decrease in NAD reduction.

Nitric oxide is produced by the cell-free system in the presence of sodium nitrite. When cell-free extract $(24 \mathrm{mg}$ protein) was incubated with $0.6 \mathrm{~mm}$-pyruvate and $40 \mathrm{~mm}$-sodium nitrite at room temperature, $420 \mathrm{nmol}$ nitric oxide were produced in $3 \mathrm{~min}$. The total amount of nitrite present was $120 \mu \mathrm{mol}$, and so total conversion was $0.4 \%$.

Nitric oxide production from sodium nitrite is increased by the presence of ascorbic acid (Evans \& McAuliffe, 1956; Riha \& Solberg, 1973). In an experiment in which $1 \mathrm{mM}$-ascorbate was included in a cell-free system containing $5 \mathrm{~mm}$-sodium nitrite, the inhibition of NAD reduction increased from 31 to $53 \%$.

\section{DISCUSSION}

The pyruvate-dependent production of carbon dioxide, acetyl phosphate and ATP with the concomitant reduction of NAD demonstrates the presence of the phosphoroclastic system in cell-free extracts of $C$. sporogenes. Hydrogenase activity appeared, however, to be absent from this system. The production of carbon dioxide and hydrogen by cell-free extracts in the presence of pyruvate has been measured in several clostridial species including C. butylicum (Koepsell \& Johnson, 1942), C. butyricum (Wolfe \& O'Kane, 1953) and C. botulinum (Simmons \& Costilow, 1962). Hydrogenase activity has been measured by production of hydrogen from dithionite-reduced ferredoxin (Valentine \& Wolfe, 1963). In the present study, however, an acidic gas, absorbed by potassium hydroxide, was produced by cell-free extracts in the presence of sodium dithionite. This gas was tentatively identified as sulphur dioxide.

In cultures, however, $C$. sporogenes produced hydrogen and carbon dioxide at an equal rate and volume which suggests that hydrogenase is present in vivo. Holdeman et al. (1977) also demonstrated production of hydrogen from glucose by $C$. sporogenes. In view of the sensitivity of hydrogenase to oxygen and its instability (Orme-Johnson \& Orme-Johnson, 
1978; Klibanov et al., 1979) we suggest that this enzyme is present in $C$. sporogenes but is destroyed during preparation of the cell-free extract.

In the present work with cell-free extracts, NAD reduction was used as a measure of the activity of the phosphoroclastic system. However, this reduction of NAD may also represent an alternative physiological fate for the reducing power liberated by the phosphoroclastic system, other than hydrogen. Thauer et al. (1969) demonstrated the production of hydrogen from reduced NAD by hydrogenase via ferredoxin in $C$. kluyveri which suggests that reduced NAD and hydrogen are alternative products from reduced ferredoxin.

In stationary phase cultures, fermentative organisms normally produce surplus reducing power and the evolution of hydrogen would represent disposal of this surplus in clostridia. Alternatively, reduction of pyruvate to lactate, butyrate, succinate, propionate, butanol and ethanol, known products of clostridial glucose fermentation (Brooks \& Moore, 1969), may also be a means for regeneration of NAD. During outgrowth of the germinated spores, however, reducing power may be required for several purposes, such as adjustment of the redox potential of the medium, detoxication of oxygen by NADH oxidase (O'Brien \& Morris, 1971) and in the synthesis of various cell constituents. In these circumstances the phosphoroclastic system (and glycolysis) would supply two components essential for the development of the cefl, i.e. ATP and reducing power, and thus most of the cell's reducing power may be used via NAD.

The effects produced in cultures of $C$. sporogenes by $4.4 \mathrm{~mm}$-nitrite with respect to the accumulation of pyruvate during continued utilization of glucose indicate that the major site of action of nitrite, at this concentration, is the phosphoroclastic system. O'Leary and Solberg (1976) have shown that nitrite at a concentration of $15 \mathrm{mM}$ will inhibit enzymes of glucose fermentation, namely glyceraldehyde-3-phosphate dehydrogenase and aldolase, in $C$. perfringens. Yarbrough et al. (1980) found that aldolase from aerobic organisms such as Escherichia coli and Pseudomonas aeruginosa was inhibited by nitrite at concentrations in the range 10 to $100 \mathrm{mM}$. It therefore seems likely that the effect of nitrite on glucose utilization which we have observed is not due to a direct effect of nitrite on the enzymes of glycolysis and is more likely to be due to a feedback inhibition of these enzymes by the accumulated pyruvate. An inhibitory effect of pyruvate on glucose utilization has been demonstrated in a number of micro-organisms including Escherichia coli (Morgan \& Kornberg, 1967), Neurospora crassa (Mattoo \& Rao, 1974) and Aspergillus nidulans (Desai \& Modi, 1977).

The rapid decrease in intracellular ATP concentrations after addition of nitrite (Fig. 1) may appear out of proportion to the theoretical $50 \%$ contribution to ATP production made by the phosphoroclastic system. However, the ATP pool within the cell is undergoing rapid turnover in maintaining ionic composition (Stouthamer, 1973), flagellar movement (Holwill, 1977) and in synthetic pathways within the cell; once ATP production drops below a certain threshold value the ATP pool would be rapidly depleted.

The experiments with cell-free extracts indicated that the observed inhibition of the phosphoroclastic system occurred by means of nitric oxide. Nitric oxide, a potent iron-ligand that forms co-ordination complexes with iron (McDonald et al., 1965; Woolum et al., 1968), could inhibit the phosphoroclastic system at either of the two non-haem iron moieties present in this system. The first of these moieties is present in ferredoxin, but we have shown that nitrite does not react directly with ferredoxin although there is a decreased activity in ferredoxin from cells preincubated with nitrite (Table 1). The second non-haem iron forms part of pyruvate:ferredoxin oxidoreductase, an enzyme which has been purified and characterized from $C$. acidiurici by Uyeda \& Rabinowitz (1971). This enzyme consists of a single protein molecule containing thiamin pyrophosphate and a non-haem iron chromophore. Reaction of nitric oxide with this non-haem iron would cause inhibition of the phosphoroclastic system especially the electron transport involved in NAD reduction and hydrogen production. 
In cell suspensions nitrite inhibits acetate and ATP production from glucose but in cell-free extracts acetyl phosphate production is not inhibited although there is an effect on ATP production in vitro. It would therefore appear that in short-term in vitro experiments the inhibitory action of nitrite on the phosphoroclastic system is not as evident as in vivo.

From studies of the inhibition of clostridia in nitrite-cured meat systems Tompkin et al. (1978) hypothesized that nitrite inhibited C. botulinum by the reaction of nitric oxide, known to be produced in cured meats, with an iron-containing protein in the cell, probably ferredoxin. Our results suggest that, while ferredoxin can react with nitric oxide in vitro, the main site of inhibition in vivo is pyruvate : ferredoxin oxidoreductase.

In conclusion, nitrite is a potent inhibitor of many species of micro-organisms, both aerobic and anaerobic, and whilst it appears that the active inhibitory agent outside the cell is closely correlated with nitrous acid (Castellani \& Niven, 1955), the mechanism of action may vary for different physiological types of micro-organism (Yarbrough et al., 1980). The results presented in this paper suggest that for $C$. sporogenes an important mechanism of nitrite inhibition is by formation of a nitric oxide complex with the non-haem iron of pyruvate:ferredoxin oxidoreductase. Further work is currently underway to extend our studies to C. botulinum.

We would like to thank Dr C. L. Walters of the Biochemistry Section for the use of the chemiluminescence analyser and the National College of Food Technology, Weybridge for lending us the Warburg manometers. This work was supported by the Ministry of Agriculture, Fisheries and Food.

\section{REFERENCES}

Brooks, J. B. \& Moore, W. E. C. (1969). Gas chromatographic analysis of amines and other compounds produced by several species of Clostridium. Canadian Journal of Microbiology 15, 1433-1447.

Bücher, T. (1955). Enolase from Brewer's yeast. Methods in Enzymology 1, 427-435.

Castellani, A. G. \& Niven, C. F. (1955). Factors affecting the bacteriostatic action of sodium nitrite. Applied Microbiology 3, 154-159.

DESAI, J. D. \& MoDi, V. V. (1977). Regulation of glucose transport in Aspergillus nidulans. Experientia 33, 726-727.

DUNCAN, C. L. \& Foster, E. M. (1968). Effect of sodium nitrite, sodium chloride and sodium nitrate on germination and outgrowth of anaerobic spores. Applied Microbiology 16, 406-411.

Evans, H. J. \& MCAuliffe, C. A. (1956). Identification of $\mathrm{NO}, \mathrm{N}_{2} \mathrm{O}$ and $\mathrm{N}_{2}$ as products of the non-enzymic reduction of nitrite by ascorbate or reduced diphosphopyridine nucleotide. In Inorganic Nitrogen Metabolism, pp. 189-197. Edited by W. P. McElroy \& B. Glass. Baltimore, Maryland, U.S.A.: Johns Hopkins University.

Glover, J. H. (1975). Chemiluminescence in gas analysis and flame-emission spectrometry. A review. Analyst 100, 449-464.

Holdeman, L. V., Cato, E. P. \& Moore, W. E. C. (1977). Anaerobe Laboratory Manual, 4th edn. Blacksburg, Virginia, U.S.A.: V.P.I. Anaerobe Laboratory.

HoLwILL, M. E. J. (1977). Some biophysical aspects of ciliary and flagellar motility. Advances in Microbial Physiology 16, 1-48.

Klibanov, A. M., Kaplan, N. O. \& Kamen, M. D. (1979). Chelating agents protect hydrogenase against oxygen inactivation. Biochimica et biophysica acta 547, 411-416.
Koepsell, H. J. \& Johnson, M. J. (1942). Dissimilation of pyruvic acid by cell-free preparations of Clostridium butylicum. Journal of Biological Chemistry 145, 379-386.

LipmanN, F. \& Tuttle, L. C. (1945). A specific micro-method for the determination of acyl phosphates. Journal of Biological Chemistry 159, 21-38.

MatToo, A. K. \& RAO, J. R. (1974). Neurospora fructose-1,6-diphosphate aldolase. Inhibition by sodium pyruvate. Biochemical and Biophysical Research Communications 60, 1229-1237.

McDonald, C. C., Phillips, W. D. \& Mower, H. F. (1965). An electron spin resonance study of some complexes of iron, nitric oxide, and anionic ligands. Journal of the American Chemical Society 87, 3319-3326.

MORGAN, M. J. \& KornberG, H. L. (1967). Effect of pyruvate on hexose metabolism by Escherichia coli. Biochemical Journal 103, 57P.

Mortenson, L. E., Valentine, R. C. \& Carnahan, J. E. (1962). An electron transport factor from Clostridium pasteurianum. Biochemical and Biophysical Research Communications 7, 448-452.

Myhrman, A., Lundin, A. \& Thore, A. (1978). The analytical application of ATP monitoring using firefly bioluminescence. LKB Application Note 314 .

O'BrIEN, R. W. \& MORRIS, J. G. (1971). Oxygen and the growth and metabolism of Clostridium acetobutylicum. Journal of General Microbiology 68, 307-318.

O'LeARY, V. \& SOlberg, M. (1976). Effect of sodium nitrite inhibition on intracellular thiol groups and on the activity of certain glycolytic enzymes in Clostridium perfringens. Applied and Environmental Microbiology 31, 208-212.

ORME-JoHnSON, E. H. \& ORME-JOHNSON, N. R. (1978). Overview of iron-sulphur proteins. Methods in Enzymology 53, 259-268. 
RiHA, W. E. \& SOLBERG, M. (1973). Instability of sodium nitrite in a chemically defined microbiological medium. Journal of Food Science 38, 1-3.

Rowe, J. J., YARBRoUGH, J. M., RAKE, J. B. \& EAGON, R. G. (1979). Nitrite inhibition of aerobic bacteria. Current Microbiology 2, 51-54.

Simmons, R. J. \& Costilow, R. N. (1962). Enzymes of glucose and pyruvate catabolism in cells, spores and germinated spores of Clostridium botulinum. Journal of Bacteriology 84, 1274-1281.

Stouthamer, A. H. (1973). A theoretical study on the amount of ATP required for synthesis of microbial cell material. Antonie van Leeuwenhoek 39, 545565.

Thauer, R. K., JungermanN, K., Rupprecht, E. \& DECKER, K. (1969). Hydrogen formation from $\mathrm{NADH}$ in cell-free extracts of Clostridium kluyveri. Acetyl-CoA requirement and ferredoxin dependence. FEBS Letters 4, 108-112.

TOMPKIN, R. B., Christiansen, L. N. \& Shaparis, A. B. (1978). Enhancing nitrite inhibition of Clostridium botulinum with isoascorbate in perishable canned cured meat. Applied and Environmental Microbiology 35, 59-61.
Umbreit, W. W., BurRis, R. H. \& StaufFer, J. F. (1957). Manometric Techniques, 3rd edn. Minneapolis, U.S.A.: Burgess Publishing Co.

UyedA, K. \& RABINowITZ, J. C. (1971). Pyruvate:ferredoxin oxidoreductase III. Purification and properties of the enzyme. Journal of Biological Chemistry 246, 3111-3119.

VAlentine, R. C. \& Wolfe, R. S. (1963). Role of ferredoxin in the metabolism of molecular hydrogen. Journal of Bacteriology 85, 1114-1120.

WOLFE, R. S. \& O'K ANE, D. J. (1953). Cofactors of the phosphoroclastic reaction of Clostridium butyricum. Journal of Biological Chemistry 205, 755-765.

Woolum, J. C., Tiezzi, E. \& Commoner, B. (1968). Electron spin resonance of iron-nitric oxide complexes with amino acids, peptides and proteins. Biochimica et biophysica acta 160, 311-320.

YARBRough, J. M., RAKE, J. B. \& EAGON, R. G. (1980). Bacterial inhibitory effects of nitrite: inhibition of active transport, but not of group translocation and of intracellular enzymes. Applied and Environmental Microbiology 39, 831-834. 